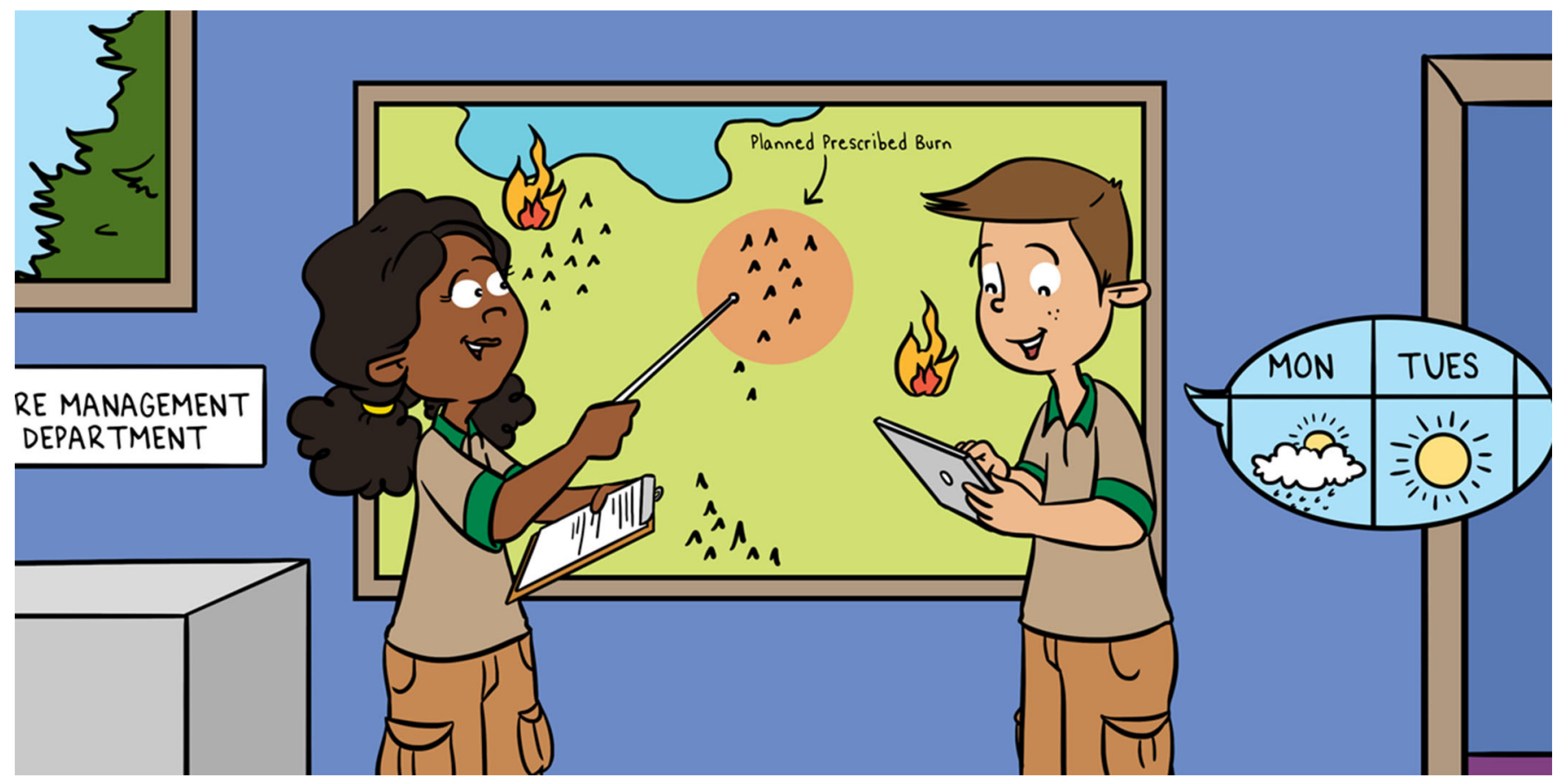

\title{
RISING FROM THE ASHES: THE ROLE OF FIRES IN NATIONAL PARKS
}

\author{
Suzanne Sanders ${ }^{1 *}$, Linda Mutch ${ }^{2}$, Mark Wasser $^{3}$, Jennifer Barnes $^{4}$ and Stephanie Perles ${ }^{5}$ \\ ${ }^{1}$ Great Lakes Inventory and Monitoring Network, National Park Service, Ashland, WI, United States \\ ${ }^{2}$ Sierra Nevada Inventory and Monitoring Network, National Park Service, Three Rivers, CA, United States \\ ${ }^{3}$ Pacific Island Inventory and Monitoring Network, National Park Service, Hawaii National Park, HI, United States \\ ${ }^{4}$ Alaska Fire Management Regional Office, National Park Service, R11 Regional Office National Park Service, Fairbanks, AK, \\ United States \\ ${ }^{5}$ Eastern Rivers and Mountains Inventory and Monitoring Network, National Park Service, University Park, PA, United States
}

\section{YOUNG REVIEWERS:}

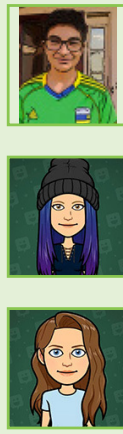

JASON

AGE: 13

TESSA

AGE: 13

VIOLET

AGE: 12
Fire is a natural and healthy part of many ecosystems, and many plant species rely on it to reproduce. Some species require the actual heat and flames for their seeds to be released and sprout. Other species rely on fire to burn off dried needles and leaves on the ground as well as many of the shrubs and small trees. This opens up the forest and allows more space and light for small plants and trees. While fire is a good thing for many plants and ecosystems, this is not the case everywhere. In areas that get high amounts of rain, ecosystems are not adapted to fire. Human-caused fires in these places can be devastating to the plants there. It is the job of fire managers and ecologists to manage wildfires, make decisions about fire suppression, and decide if additional fires are needed in key ecosystems. 


\section{SURFACE FIRE}

A fire that burns just above the ground. This typically burns old leaves and needles as well as living grasses and plants and allows more sunlight to reach the ground.

\section{CROWN FIRE}

A fire that burns the top part of the tree, where the leaves or needles are.

\section{CANOPY}

The highest part of a forest, including the leaves or needles and upper branches.

\section{SEROTINOUS CONE}

A cone of a conifer tree that is closed shut by a substance called resin. When a crown fire happens, the resin burns off, and the cone releases its seeds.

\section{FIRE REGIME}

The pattern of naturally occurring fires. The fire regime of an area includes such information as the length of time between fires and whether they are surface or crown fires.

\section{ARE FOREST FIRES A GOOD THING OR A BAD THING?}

We have all seen images of raging forest fires that leave scorched bare ground and trees blackened like charcoal. As our climate changes, some wildfires are becoming more severe, killing trees that typically survived past fires. Many people do not realize, however, that fire is an important natural process in a variety of forests. Some ecosystems require fire to remain healthy, and the plants and animals that inhabit these places are adapted to periodic burns [1]. Some trees have thick bark that acts as insulation to protect them from fire, or cones that open and disperse seeds only after experiencing high heat from a burn [2]. After a fire, new trees and plants grow in the area that burned. For ecosystems that are adapted to fire, you can think of it as nature's way of hitting the reset button. Unfortunately, people did not always recognize the importance of fire.

For many years, people actively suppressed fires. This means people put out all forest fires as quickly as possible. Many of the problems that we see with large, intense wildfires today are the result of years of fire suppression. For example, in the absence of fire, fuel can build up. Fuel can include both living vegetation, such as shrubs and mosses, as well as dead trees that are still standing or have already fallen. Fire suppression over many decades results in conditions that are unhealthy for the forest and dangerous to humans [3]. Fortunately, scientists now see the important role that fire plays.

\section{TYPES OF FIRES}

Fire ecologists (scientists who study forest fires) classify fires into two main types, although combinations of the two can also happen. Surface fires burn the grasses and broad-leaved plants that grow just above the ground level (Figure 1). Grasses are especially well-adapted to survive surface fires. Crown fires burn the canopy, or the top parts of trees where the leaves grow (Figure 1). Where crown fires occur, trees with serotinous cones release their seeds. Serotinous cones only release seeds after they are exposed to the high heat of a fire. Other traits used to classify fires include severity, frequency of occurrence in a given region, and size. All of these characterize the fire regime for a place, which is closely tied to the local plants and climate or, in other words, the local ecosystem.

\section{FIRE IS IMPORTANT IN MANY ECOSYSTEMS...BUT NOT ALL니}

In the Appalachian Mountains, oaks are the most common trees in the oak-hickory forests that stretch for hundreds of miles along the ridgetops from Alabama to New York. Animals of all sizes depend on the oaks, from the insects that hide in the trees' craggy bark, to the 
Figure 1

The two main types of forest fires are surface fires (left) and crown fires (right). Surface fires burn off the leaves and kill small saplings of species not adapted to fire. The ground becomes a blank canvas with high light creating perfect conditions for seedlings of fire-adapted species to take hold. In crown fires, the cones of the mature, large trees open up in the heat and flames and their seeds scatter on the forest floor. The seedlings that grow from these seeds thrive in the high light of this new environment. Photos: Left: NPS, Right: Chris Havener.

\section{UNDERSTORY}

The lowest layer of the forests. This includes grasses, herbs, shrubs, and very small trees.

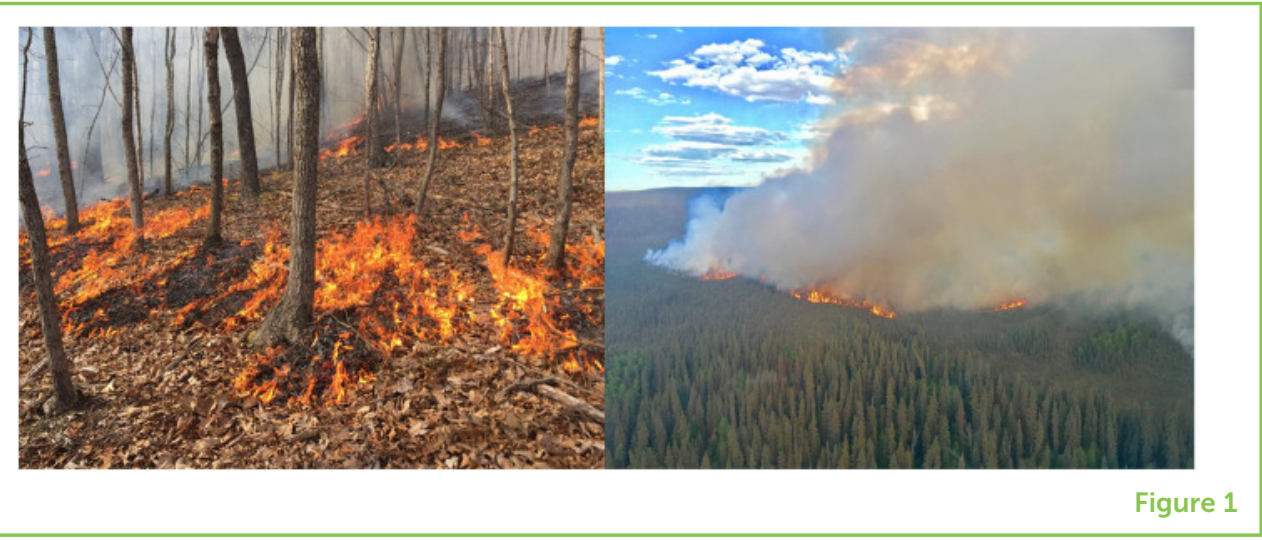

chipmunks and black bears that rely on acorns (the oaks' seeds) to survive long, cold winters. Adult oak trees have thick bark that protects them from surface fires, while young oaks have long, thick roots full of nutrients, to fuel the trees' regrowth after fire. But Appalachian oak forests have a problem. After decades of fire suppression, the oak seedlings sprouting from acorns do not have enough sunlight or space on the forest floor to grow into mature trees [4]. Surface fires create the right environment for oak seedlings to thrive, by creating openings in the forest canopy and removing tree species such as maples that create dense shade. Surface fires allow oak forests to regenerate, and these fires protect habitat for thousands of plants and animals in the Appalachian Mountains.

In savannas of the upper Midwest, black oaks and bur oaks dominate the landscape, while the understory species include not only grasses, but also broad-leaved species that are important to pollinators, and blueberries, which feed wildlife. Here, fire ecologists strive to maintain open conditions so that these important understory species can persist. The goal is to burn often enough so that there is generally not more than $40 \%$ canopy closure (you can think of this as $60 \%$ open sky). This helps ensure that important understory species receive enough light to survive and reproduce.

Of course, fire is important not only for oaks, but for conifers, or "evergreen" tree species, as well. In the Sierra Nevada mountains of California, giant sequoias are known for their size, long lifespan, and need for fire. Scientists who examine tree-ring samples have shown that fires burned often in the past, occurring every 6 to 35 years [5]. When managers suppressed fires for many decades, the number of young sequoias sharply declined. Why did that happen? Fire plays a key role in the sequoia life cycle. Serotinous cones high up in the trees release many seeds when exposed to heat from a fire. Fire also uncovers bare soil by burning dead branches and leaves. The sequoia seeds, and eventual seedlings, need bare soil to take root, and sunny gaps in which to grow. Adult sequoias have survived most fires because their thick bark resists burning and protects them from a 
Figure 2

Firefighters conducting a prescribed burn in a giant sequoia forest in central California. They use drip torches to ignite material on the ground. Prescribed fires are carefully planned, and firefighters use natural barriers (like large rocks and trails) as well as additional

"fireline" that they dig to remove burnable materials and contain the fire within a specific area. Prescribed burns can range in size from tens to hundreds to thousands of hectares depending on location, objectives, and safety considerations. Photo: Tony Caprio.

\section{PRESCRIBED BURN}

An intentional fire that fire managers conduct for the benefit of plants, animals, and soil. Managers ensure that the burn is carried out in a safe and controlled manner.

\section{BOREAL FOREST}

The northernmost, and most extensive, forest type in the world. In North America, boreal forest extends from Alaska across Canada and into the Great Lakes region of the United States.

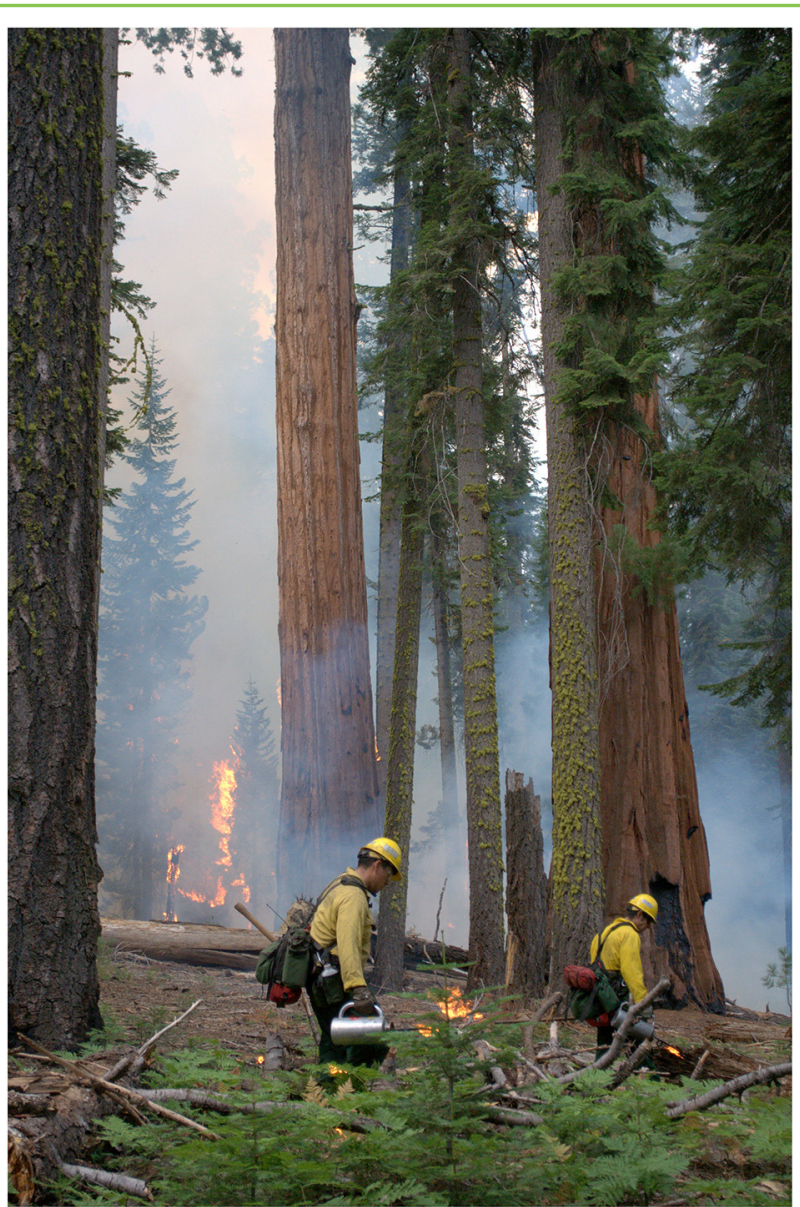

Figure 2

fire's heat. Since the 1970s, fire managers have used prescribed burns and lightning-ignited fires to restore fire to sequoia forests (Figure 2). Scientists monitoring the forest after fires find young sequoias are more abundant again.

Fires are also common in other western conifer forests. Many people are aware of fires in the western United States; fewer people realize how important fire is in Alaska. The summers in interior Alaska can be warm and lightning is common. The black spruce forest, or boreal forest, is adapted to both surface and crown fires and is designed to burn. Low-hanging branches drape into the flammable moss layer and ground vegetation. When a fire starts, it spreads across the ground and up to the crown of the tree-a crown fire! Although the trees are not well-protected from fire, the seed cones at the top of the trees are serotinous, so seeds are released, rejuvenating the forest. Young black spruce seedlings often begin to grow in the first 5 to 10 years after a fire (Figure 3). Shrubs and leafy trees such as birch and aspen come back quickly after fire, either from seeds or by re-sprouting from below-ground roots. These young forests are important for wildlife. Moose browse the leafy shrubs and trees and voles eat the new green plants. Voles are prey for other animals, including owls, fox, and 
Figure 3

A black spruce site in Alaska. The photo on the left was taken 2 years after a fire that burned both the crown and the surface. Note the grasses that are already abundant. The figure on the right is the same site 15 years after the fire. Note that there are multiple black spruce saplings visible in the photo, and that many of the dead trees have fallen. The scientists in these photos are monitoring the numbers and types of plants that have grown back after the fire at different time periods. Photo: NPS.

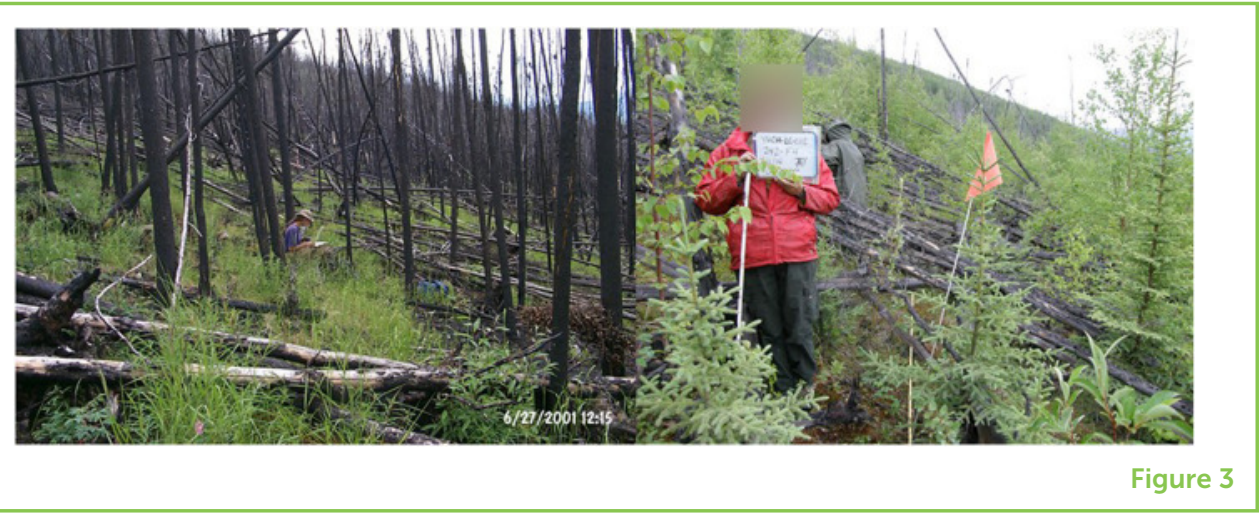

marten. Fire is a necessary part of the landscape in Alaska. Rather than being suppressed, many fires are managed, not only to protect people and communities, but also to help the forests and wildlife.

In contrast to Alaska, Hawai'i is quite different. Fire is usually very harmful to Hawai'i's native vegetation. Before people settled on these islands, fire was uncommon, mainly because lightning is not common [6]. Hawai'i has fewer native plant species than does the United States mainland. The plants that do grow there have adaptations that helped them to disperse across the ocean (such as seeds that could float, or had "wings"), but not to survive fires. Fires are now common in Hawai'i-most are accidentally started by people. These fires destroy the native vegetation, and the native plants are not good at recovering after this happens. One of the biggest problems is non-native species. These are brought over from elsewhere-usually accidentally-and they are sometimes much better at dealing with fire. After a fire, these non-native species often grow so quickly that the native plants cannot keep up with them, and do not ever grow back. Because of this, we try to put out fires in Hawai'i as quickly as we can!

\section{MANAGING FIRE IS A BALANCE BETWEEN RISKS AND BENEFITS}

Most national parks have developed fire-management plans that identify priorities and approaches for managing wildfires. Unplanned, human-caused fires are nearly always suppressed as soon as possible, since they usually occur in places or under conditions where they may threaten human life or property, as well as natural or cultural resources like wildlife, plants, or historic buildings. At higher elevations or in remote wilderness, lightning-caused fires may be managed and monitored if they do not cause threats to human life or property. These fires may benefit forests, meadows, shrublands, or other park ecosystems.

Some national parks also conduct prescribed burns. Each year, park managers identify the type, number, and timing of prescribed burns 
they hope to conduct. For a prescribed fire to be approved, certain conditions must be met. The weather must be favorable (without extreme winds or very dry conditions) and enough fire staff must be available to manage the fire.

\section{WE NEED FIRE}

Fire is a natural, important process in many ecosystems. Without it, fire-dependent forest types will be lost from national parks, eliminating important habitats for animals and plants that depend on these forests. Decades of fire suppression and a changing climate can contribute to extremely severe fires that convert forests into other vegetation types, such as shrublands or grasslands. Therefore, for forests adapted to periodic fire, it is important that the National Park Service and other land management agencies allow fires that start from natural sources to burn when possible, in addition to conducting prescribed burns. This will result in healthier forests, improved wildlife habitats, and safer conditions for people who live near or spend time in forests.

\section{REFERENCES}

1. Pausas, J. G., and Keeley, J. E. 2019. Wildfires as an ecosystem service. Front. Ecol. Environ. 17:289-95. doi: 10.1002/fee.2044

2. Schwilk, D. W., and Ackerly, D. D. 2002. Flammability and serotiny as strategies: correlated evolution in pines. Oikos 94:326-36. doi: 10.1034/j.1600-0706. 2001.940213.x

3. Turner, M. G., Romme, W. H., and Tinker, D. B. 2003. Surprises and lessons from the 1988 Yellowstone fires. Front. Ecol. Environ. 1:351-8. doi: 10.1890/15409295(2003)001[0351:SALFTY]2.0.CO;2

4. Brose, P. H., Dey, D. C., and Waldrop, T. A. 2014. The Fire-Oak Literature of Eastern North America; Synthesis and Guidelines. General Technical Report NRS-135. Newtown Square, PA: U.S. Department of Agriculture, Forest Service, Northern Research Station.

5. Swetnam, T. W., Baisan, C. H., Caprio, A. C., Brown, P. M., Touchan, R., Anderson, R. C., et al. 2009. Multi-millennial fire history of the Giant Forest, Sequoia National Park. Fire Ecol. 5:120-50. doi: 10.4996/fireecology.0503120

6. Smith, C. W., and Tunison, J. T. 1992. "Fire and alien plants in Hawai'i: research and management implications for native ecosystems," in Alien Plant Invasions in Native Ecosystems in Hawaii: Management and Research, Stone, C. P., Smith, C. W. and Tunison J. T. (eds). Honolulu: University of Hawai'i Press. p. 394-408.

SUBMITTED: 09 November 2020; ACCEPTED: 13 October 2021; PUBLISHED ONLINE: 29 November 2021.

EDITED BY: Rebecca Weissinger, National Park Service, United States

CITATION: Sanders S, Mutch L, Wasser M, Barnes J and Perles S (2021) Rising From the Ashes: The Role of Fires in National Parks. Front. Young Minds 9:627635. doi: 10.3389/frym.2021.627635 


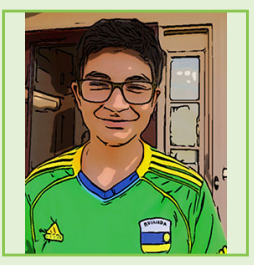

CONFLICT OF INTEREST: The authors declare that the research was conducted in the absence of any commercial or financial relationships that could be construed as a potential conflict of interest.

COPYRIGHT (c) 2021 Sanders, Mutch, Wasser, Barnes and Perles. This is an open-access article distributed under the terms of the Creative Commons Attribution License (CC BY). The use, distribution or reproduction in other forums is permitted, provided the original author(s) and the copyright owner(s) are credited and that the original publication in this journal is cited, in accordance with accepted academic practice. No use, distribution or reproduction is permitted which does not comply with these terms.

\section{YOUNG REVIEWERS}

\section{JASON, AGE: 13}

Hi! My name is Jason. I like science and I want to study paleontology in college.

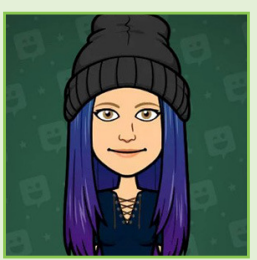

\section{TESSA, AGE: 13}

My name is Tessa and I live in Oregon. I can remember many summers with long days of bad wildfire smoke. I like to read fantasy books. I am also interested in the evolutionary biology of unicorns.

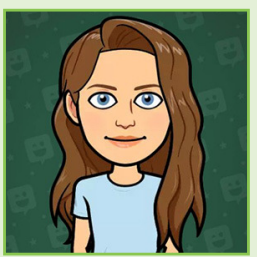

\section{VIOLET, AGE: 12}

My name is Violet. I live in Oregon. I am 12 years old and my hobbies are skiing and kayaking. I love reading. My favorite book is Number The Stars by Louis Lowry. I like walking downtown with my friends and looking in the store windows.

\section{AUTHORS}

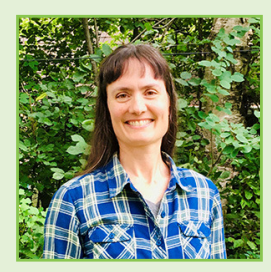

\section{SUZANNE SANDERS}

Suzanne Sanders is a forest ecologist with the National Park Service, working at nine national parks in the Great Lakes region. She studies how forests respond to natural and human-caused changes in the environment. In her free time, she enjoys getting out and biking or skiing on the trails of northern Minnesota. *suzanne_sanders@anps.gov

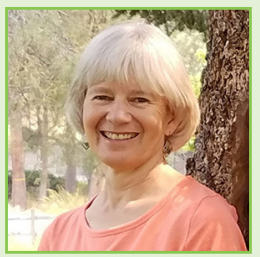

\section{LINDA MUTCH}

Linda Mutch is a science communication specialist with the Inventory and Monitoring Division of the National Park Service. She uses a variety of methods to communicate science findings to different audiences, from national park managers to the public. She previously worked as a forest ecologist and as a firefighter. She loves to hike, bike, ski, and go birding. 


\section{MARK WASSER}

Mark Wasser is an interdisciplinary biologist with the Inventory and Monitoring Division of the National Park Service in Hawai'i. He mostly makes maps, but he also works to bring scientists and fire managers together during fire responses, and to help firefighters do their jobs while protecting resources and plant communities. Mark loves to hike, fish, and grow plants, but is very bad at surfing.

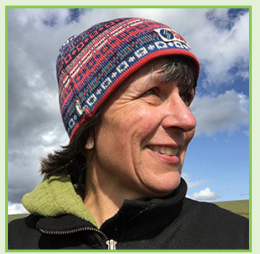

\section{JENNIFER BARNES}

Jennifer Barnes is a fire ecologist with the National Park Service in Alaska. She studies what happens before, during, and after a fire. Her work helps fire managers understand how fires burn and the effects of fire on vegetation, soils, and wildlife habitat. Jennifer loves to garden, fish, and ski in Alaska.

\section{STEPHANIE PERLES}

Stephanie Perles is a plant ecologist with the Inventory and Monitoring Division of the National Park Service. She studies how forests in national parks are changing, so that parks managers can use forest health data to protect healthy, resilient forests in parks. When not hiking in the forest looking at plants, Stephanie enjoys gardening and biking. 